\title{
Adaptation of Bacillus subtilis Cells to Archean-Like UV Climate: Relevant Hints of Microbial Evolution to Remarkably Increased Radiation Resistance
}

\author{
Marko Wassmann, Ralf Moeller, Günther Reitz, and Petra Rettberg
}

\begin{abstract}
In a precursory study for the space experiment ADAPT ("Molecular adaptation strategies of microorganisms to different space and planetary UV climate conditions"), cells of Bacillus subtilis 168 were continuously cultured for 700 generations under periodic polychromatic UV irradiation $(200-400 \mathrm{~nm})$ to model the suggested UV radiation environment on early Earth at the origin of the first microbial ecosystem during the Archean eon when Earth lacked a significant ozone layer. Populations that evolved under UV stress were about 3-fold more resistant than the ancestral and non-UV-evolved populations. UV-evolved cells were 7-fold more resistant to ionizing radiation than their non-UV-exposed evolved relatives and ancestor. In addition to the acquired increased UV resistance, further changes in microbial stress response to hydrogen peroxide, increased salinity, and desiccation were observed in UV-evolved cells. This indicates that UV-sensitive ancestral cells are capable of adapting to periodically applied UV stress via the evolution of cells with an increased UV resistance level and further enhanced responses to other environmental stressors, which thereby allows them to survive and reproduce under extreme UV radiation as a selection pressure. Key Words: UV radiation-Ionizing radiation-Experimental evolutionRadiation resistance-Adaptation-Stress response-Bacillus subtilis. Astrobiology 10, 605-615.
\end{abstract}

\section{Introduction}

$\mathbf{U}$ LTRAVIOLET RADIATION has been a ubiquitous environmental stress factor since the origin of the first microbial ecosystem during the Archean eon. Then, Earth lacked a significant ozone layer and was exposed to a more energy-rich UV radiation spectrum than today, with the occurrence of wavelengths down to about $200 \mathrm{~nm}$ (Walker et al., 1983; Lowe, 1994; Holland, 1999, 2006). Any organisms living in the upper water layer of the oceans as well as primary colonizers of surface habitats on Earth were vulnerable to the effect of solar UV radiation. Hence, microorganisms that survived at the surface of early Earth without the protection of an ozone layer would have needed mechanisms to resist UV radiation.

Evolution can be described as the genetic strategy to adapt to, and survive, changing environmental conditions, for example, solar UV radiation. UV irradiation has several deleterious effects on the cellular level that cause a variety of lesions, mainly DNA base damage, strand breaks, proteinDNA crosslinks, membrane peroxidation, and enzyme in- activation (Cadet et al., 2005; Goosen and Moolenaar, 2008, and references therein). Due to the potential lethal effects of UV radiation, organisms need to respond and adapt quite rapidly to a change in the UV environment. As cellular DNA is the most critical target with regard to cell lethality, there is the necessity of a complex array of enzymatic DNA repair systems to maintain cell functionality. These enzymatic repair pathways generated during evolution are well suited for repairing DNA damage that occurs after exposure to natural radiation levels but not for repairing the large amount of DNA lesions induced during a laboratory experiment like that described in this publication. Here, fluences were used that are orders of magnitude larger than cells would have encountered during natural evolution, which showed that the possibility for further evolution could exist (Ewing, 1995).

Bacteria are optimal model systems for experimentally addressing important evolutionary genetic questions. Due to their short reproduction times, in addition to other advantages such as easily controlled and replicated environments, 
large populations, and small space requirements, evolution can be observed in real time by using laboratory populations (reviewed in Elena and Lenski, 2003). Phenotypic and genotypic differences can be monitored, while major evolutionary changes occur in experimental populations during one single controlled experiment (Lenski et al., 1991; Rosenzweig et al., 1994; Sniegowski et al., 1997; Rainey and Travisano, 1998).

In this paper, we introduce our study on Bacillus subtilis 168 , which was carried out within the framework of the space experiment ADAPT ("Molecular adaptation strategies of microorganisms to different space and planetary UV climate conditions," see http://www.go.dlr.de/musc/expose/ expose_e.php). In brief, the hypothesis to be tested experimentally in ADAPT is whether longer-lasting selective pressure by UV radiation of different quality results in a higher UV resistance as well as a higher resistance against the simultaneous action of further extreme environmental factors that exist in space or on other planets, such as vacuum, desiccation, or cosmic radiation. The ESA facility Expose-E on EuTEF (European Technology Exposure Facility, see http://www.spaceflight.esa.int/users) on the International Space Station was used from February 2008 until September 2009 to investigate the different adaptation and survival strategies of three highly resistant microorganisms: the cyanobacterium Anabaena cylindrica, the halophilic archaeon Halococcus dombrowskii, and the Gram-positive bacterium B. subtilis. For this purpose, we designed an experimental evolution system with UV stress as a selection force. The aim of our study was to determine the adaptiveness of $B$. subtilis under laboratory conditions and produce stable strains that adapt to the applied stress for further studies. So far, most studies of UV effects on organisms have been restricted to one wavelength, mostly $254 \mathrm{~nm}$ UVC, although the natural solar UV radiation field is of polychromatic nature. For this work, we decided to use a radiation spectrum in the range of $200-400 \mathrm{~nm}$ wavelengths, which represents the given UV climate at the time when repair pathways were generated during microbial evolution in the Archean eon $(4.0-2.5 \mathrm{Ga})$.

\section{Materials and Methods}

\subsection{Bacterial strains and growth conditions}

Bacillus subtilis strains and populations used in this study are listed in Table 1.

\subsection{Cultivation}

Bacillus subtilis trpC2 strain 168 (DSM 402) was obtained from the German Collection of Microorganisms and Cell Cultures (DSMZ), Braunschweig, Germany. Vegetative cells of $B$. subtilis were cultivated under conditions that repress sporulation in liquid nutrient broth (NB) medium (MP Biomedicals Inc., Solon, USA), which consists of $1 \%(\mathrm{w} / \mathrm{v}) \mathrm{D}(+)-$ glucose monohydrate (Merck KGaA, Darmstadt, Germany) as described in detail by Maughan et al. (2007). Glucose was added as an additional carbon source and known inhibitor of the sporulation response (Grossman, 1995). In this regard, the populations were not likely even to initiate spore development and therefore would not expend the energy associated with spore formation (Maughan et al., 2007). Cells were cultivated under aerated growth conditions (agitation, $200 \mathrm{rpm}$ ) at $37^{\circ} \mathrm{C}$ for $20 \mathrm{~h}$. Viable counts were determined by plating cells on NB medium with the addition of agar to $2 \%$ final concentration. Serial 10-fold dilutions of cultures made in phosphate-buffered saline (PBS; $10 \mathrm{mM} \mathrm{K}_{2} \mathrm{HPO}_{4}, 150 \mathrm{mM}$ $\mathrm{NaCl}, \mathrm{pH}$ 7.2) (Nicholson and Setlow, 1990) were plated and incubated for $20 \mathrm{~h}$ at $37^{\circ} \mathrm{C}$.

\subsection{Experimental evolution setup}

To determine the effect of continuous cultivation and periodic UV exposure, the following experimental setup was used: from a stock collection of B. subtilis 168 endospores, an aliquot was plated on NB medium. One individual colony was picked to inoculate a starting culture. From this monoclonal $B$. subtilis 168 culture, approximately $10^{4}$ cells were used to inoculate $30 \mathrm{ml}$ sterile NB medium, which represented the ancestral population (A). The cell suspension was cultured for $20 \mathrm{~h}$ under vigorous aeration at $37^{\circ} \mathrm{C}$, until the culture was in the stationary growth phase

Table 1. Bacterial Strains and Population Used in This Study

\begin{tabular}{|c|c|c|}
\hline Strain & Origin or experimental background & Source or description (reference) \\
\hline $\begin{array}{l}\text { Bacillus subtilis trpC2 } \\
\text { strain } 168 \text { (DSM 402) }\end{array}$ & Ancestral strain $(\mathrm{A})$ & $\begin{array}{l}\text { German Collection of Microorganisms and } \\
\text { Cell Cultures (DSMZ), Braunschweig, } \\
\text { Germany (Spizizen, 1958) }\end{array}$ \\
\hline Bacillus subtilis MW01 & $\begin{array}{l}\text { Isolated from population 1E69 } \\
\text { (evolved under UV stress) }\end{array}$ & This study \\
\hline Bacillus subtilis DE69 & $\begin{array}{l}\text { Isolated from population C69 } \\
\text { (evolved without UV exposure) }\end{array}$ & This study \\
\hline \multicolumn{3}{|c|}{ Mixed populations derived from ancestral strain: } \\
\hline 1E69 & Evolved population of line 1 after 69 transfers & This study \\
\hline E10-E69 & $\begin{array}{l}\text { Populations of line } 1 \text { after indicated } \\
\text { number of transfers }\end{array}$ & This study \\
\hline 2E69 & Evolved population of line 2 after 69 transfers & This study \\
\hline 3E69 & Evolved population of line 3 after 69 transfers & This study \\
\hline $4 \mathrm{E} 69$ & Evolved population of line 4 after 69 transfers & This study \\
\hline C69 & $\begin{array}{l}\text { Evolved population of the control } \\
\text { line after } 69 \text { transfers }\end{array}$ & This study \\
\hline
\end{tabular}


(measured by optical density readings at $600 \mathrm{~nm}$ of $0.8 \pm 0.2)$ and physiologically acclimated to the new environment. The number of spores was determined by heat shocking an aliquot at $80^{\circ} \mathrm{C}$ for $10 \mathrm{~min}$, a common pasteurization process that is sufficient to ensure that only spores survive and vegetative cells are killed (Maughan et al., 2006). Only vegetative B. subtilis cell suspensions with a content of spores below $0.01 \%$ were used for all further treatments. Four parallel populations, designated in the following as $1 \mathrm{E}$ through $4 \mathrm{E}$, were started as follows: $10^{7}$ stationary-phase cells of the $20 \mathrm{~h}$ culture were transferred into $30 \mathrm{ml}$ of sterile NB medium (dilution factor 1:50) and UV irradiated at $4{ }^{\circ} \mathrm{C}$ in parallel with a fluence of $16.8 \mathrm{~kJ} / \mathrm{m}^{2}$ in a range of $200-400 \mathrm{~nm}$ by using a Sunlight Simulator [Sunlight Simulator SOL 2, Dr. Hönle AG, UV-Technology, Munich, Germany; the applied spectrum is shown by Moeller et al. (2005)]. Attenuation by the cells themselves was diminished by magnetic stirring during the irradiation. After irradiation, the suspensions were incubated immediately at $37^{\circ} \mathrm{C}$, and the surviving populations (named 1E01 through 4E01, with 01 indicating the number of elapsed passage cycles) were grown overnight to stationary phase. After $20 \mathrm{~h}$, a sample of each population was identically treated as described above and further serially numbered. A control population (C), also started from the ancestral population, was cultured in parallel without UV exposure. This procedure represents one typical passage cycle and was repeated 68 times. Aliquots of each passage cycle were taken before and after every UV irradiation for survival analysis. To assess survival, the colony-forming assay was applied. In short, colony formation was determined from appropriate dilutions in PBS for B. subtilis cells after incubation at $37^{\circ} \mathrm{C}$ overnight on nutrient broth agar plates (Difco Detroit, USA) (Moeller et al., 2007a, 2007b). Culturing and irradiation was carried out in UV-translucent $250 \mathrm{ml}$ quartz flasks (QCS GmbH, Maintal, Germany) to minimize transfers. A sketch of the experimental setup and a working flow, all routinely used microbiological methods, is shown in Fig. 1.

\subsection{Sampling}

Mixed population samples, which contained the variation present in the population in that passage cycle (not clonal samples) and were taken from the evolving populations, were obtained after overnight growth at every completed cycle by adding $300 \mu \mathrm{l}$ glycerol $87 \%$ (v/v) to $1 \mathrm{ml}$ of culture, resulting in a final concentration of $20 \%(\mathrm{v} / \mathrm{v})$ glycerol per sample and storing immediately at $-80^{\circ} \mathrm{C}$.

\subsection{Effective population size estimates}

Effective population sizes were estimated as described by Maughan et al. (2006). In brief, data from viable counts taken each day throughout the 69-cycle experiment provided two important variables: the number of cells in a population after overnight growth and the number of elapsed generations in each $24 \mathrm{~h}$ period, which was computed via the equation: $\ln \left(N_{24} / N_{0}\right) / \ln (2)$, where $N_{24}$ and $N_{0}$ were the viable cell counts at $24 \mathrm{~h}$ and $0 \mathrm{~h}$, respectively. Overnight growth densities, dilution ratios (during daily inoculation, which imposes a bottleneck), and number of generations were used to solve for effective population size.

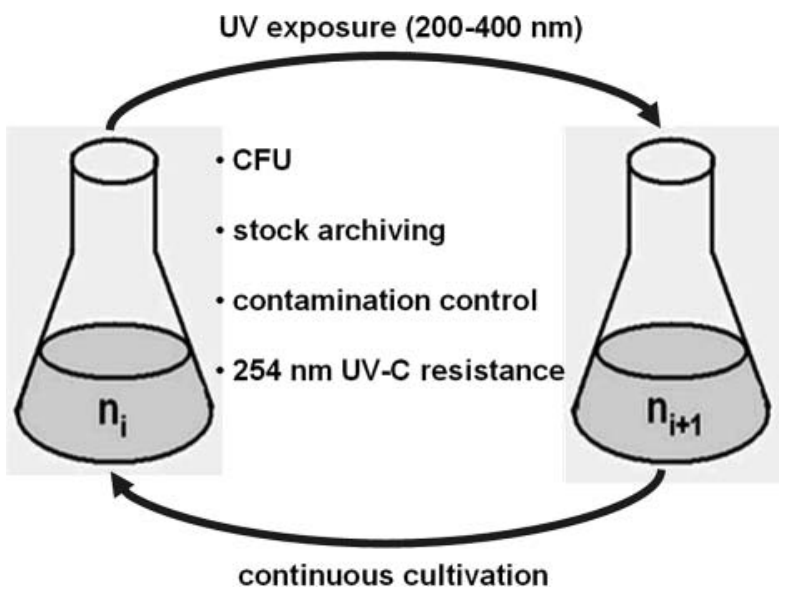

FIG. 1. Sketch of the experimental setup for studying microbial adaptation to recurring UV exposure and subsequent continuous cultivation. The listing in the working flow diagram represents the microbiological methods used (i.e., CFU colony-forming ability, archiving of passages, contamination control by PCR, stress response assays) to determine the degree of adaptation to UV stress and monitoring of the cultivation.

\subsection{Control of taxonomic identity}

To ensure the taxonomic identity of the cultivated organism, the composition of the continuous cultures was observed every $10^{\text {th }}$ cycle genetically via polymerase chain reaction (PCR) as follows: various colonies were picked and incubated in $5 \mathrm{ml} \mathrm{NB}$ medium overnight at $37^{\circ} \mathrm{C}, 1 \mathrm{ml}$ culture was centrifuged at $12,000 \mathrm{~g}$ for $5 \mathrm{~min}$ at $4^{\circ} \mathrm{C}$, and the pellet was resuspended in $0.2 \mathrm{ml}$ TE buffer $(10 \mathrm{mM}$ Tris- $\mathrm{HCl}, 1 \mathrm{mM}$ $\mathrm{Na}_{2}$ EDTA, pH 8.0). The total genomic DNA was extracted from the samples by using a chloroform-phenol extraction protocol (Entcheva et al., 2001). Purified DNA was stored in twice distilled water at $4{ }^{\circ} \mathrm{C}$ for further analysis. Partial sequence analysis of $16 \mathrm{~S}$ rDNA was used as described by Fajardo-Cavazos and Nicholson (2006) and Rettberg et al. (2006). The sequenced region of $r m A-16 S$ was amplified by PCR by using the universal primers 27F (5'-GAGTTT GATCMTGGCTCAG-3'; Lane, 1991) and 1492R (5'-CGGY TACCTTGTTACGAC-3'; Kane et al., 1993). All primers were synthesized by MWG Biotech AG, Ebersberg, Germany. Each PCR reaction was performed on $5 \mu \mathrm{l}$ template DNA $(0.2-0.15 \mu \mathrm{g}$ DNA $/ \mu \mathrm{l})$, with each $1 \mu \mathrm{l}$ pmol of the primer pairs, $25 \mu \mathrm{l} \mathrm{H}_{2} \mathrm{O}$ and $20 \mu \mathrm{l} \mathrm{PCR}$ ready-to-use mixture (HotStart-PCR Kit, Qiagen, Hilden, Germany) in 35 thermal cycles of 95,60 , and $72^{\circ} \mathrm{C}$ for 45,60 , and $90 \mathrm{~s}$, respectively (MiniCycler Bio-Rad, CA, USA). The PCR products were resolved by agarose gel electrophoresis as described by Nellen et al. (2006). Sequencing was carried out by AGOWA $\mathrm{GmbH}$, Berlin, Germany. Taxonomic identity was determined by applying the NCBI-BLAST program (http:// www.ncbi.nlm.nih.gov).

Additionally, marker tests were performed by making use of the tryptophan auxotrophy of B. subtilis trpC2 strain 168. Cultures were serially 10-fold diluted and plated on glucose minimal medium (Anagnostopoulos and Spizizen, 1961) with and without a supplement of $0.5 \%(\mathrm{w} / \mathrm{v})$ L-tryptophan (Sigma-Aldrich Chemie GmbH, Steinheim, Germany) and on 
NB medium. After overnight incubation at $37^{\circ} \mathrm{C}$ on $\mathrm{NB}$ medium and $48 \mathrm{~h}$ of incubation at $37^{\circ} \mathrm{C}$ on glucose minimal medium, colonies were counted. By definition, B. subtilis trpC2 strain 168 is unable to grow on minimal medium without a supplement of L-tryptophan (Zeigler et al., 2008).

\subsection{Resistance assays}

Stationary-phase cells from overnight cultures were harvested by centrifugation at $4,000 \mathrm{~g}$ for $15 \mathrm{~min}$ at $4{ }^{\circ} \mathrm{C}$ and resuspended in PBS $\left(10^{7}\right.$ cells $/ \mathrm{ml}$, if not mentioned otherwise). All resistance assays below were performed by using suspensions with a content of spores below $0.01 \%$. All experiments were repeated three or four times.

2.7.1. UV resistance assay. To measure the sensitivity of vegetative cells of the respective generations to UVC radiation, cells were exposed at $4{ }^{\circ} \mathrm{C}$ to monochromatic UVC radiation emitted by a mercury low-pressure lamp (NN 8/ 15 , Heraeus, Berlin, Germany) with a major emission line at $254 \mathrm{~nm}$. The spectral irradiance was determined spectrophotometrically (Bentham 150 double monochromator), and the fluence rate was $90.5 \mu \mathrm{W} / \mathrm{cm}^{2}$ as measured with a regularly calibrated UVX radiometer fitted with a UVX-25 filter (UVP Ultra-Violet Products, Cambridge, UK) (Moeller et al., 2005; Pogoda de la Vega et al., 2005; Fajardo-Cavazos and Nicholson, 2006). Irradiation and survival determination were carried out under conditions described above. UV inactivation curves were determined and used to compute the average UV fluence required to reduce the population to $10 \%$ $\left(F_{10}\right)$.

2.7.2. X-ray resistance assay. In analogy to the UVC resistance determination assay, cells were irradiated at room temperature with X-rays $(150 \mathrm{keV} / 19 \mathrm{~mA})$ generated by an X-ray tube (Mueller type MG 150, MCN 165; Philips, Hamburg, Germany). Radiation dosimetry and dose calculations were used as described in detail by Moeller et al. (2008). Cell survival was determined as described above.

2.7.3. Desiccation resistance assay. In accordance with Beblo et al. (2009), approximately $10^{8}$ cells of populations A, C69, and 1E69 were spread evenly on glass discs and dried $6-8 \mathrm{~h}$ under laboratory conditions at room temperature (relative humidity of the atmosphere $33.4 \pm 3.5 \%$ ). After drying, the samples were stored under laboratory conditions for 24, 48,120 , and $168 \mathrm{~h}$. To resuspend the cells, the glass discs with desiccated cells were transferred into $1 \mathrm{ml}$ of PBS and incubated for $1 \mathrm{~h}$. Survivors were enumerated as described above.

2.7.4. Heat resistance assay. To assay for heat resistance (after Hanlin et al., 1985), $5 \mathrm{ml}$ suspension of cells in PBS were transferred into $10 \mathrm{ml}$ glass test tubes. The tubes were heated in a water bath at $55^{\circ} \mathrm{C}$ for the indicated time. One minute was allowed for warm-up. After heating, survival was determined as described above.

2.7.5. Hydrogen peroxide resistance assay. Ten-milliliter suspension of cells in PBS were transferred into prewarmed $100 \mathrm{ml}$ culture flasks. Hydrogen peroxide was present in the flasks so that the concentration came to $10 \mathrm{mM}$ immediately after addition of the cells, as described in detail by Helmann et al. (2003). The solutions were shaken at $200 \mathrm{rpm}$ at $37^{\circ} \mathrm{C}$. Samples were taken at regular intervals and appropriately diluted in PBS. Cell survival was determined as described above.

2.7.6. Salt stress tolerance assay. Survival curves were recorded by transferring cells into hyperosmotic PBS (adding $1 \mathrm{M} \mathrm{NaCl}$ to the basal PBS) and sampling at regular intervals, as reported by Steil et al. (2003). Samples were appropriately diluted in PBS, and cell survival was determined as described above.

\subsection{Numerical and statistical analysis}

The surviving fraction of the vegetative cells and spores was determined from the quotient $N / N_{0}$, with $N=$ the number of colony-forming units of the irradiated sample and $N_{0}$ that of the non-irradiated controls. Data are reported as $D_{10}$ (for $X$-rays) and $F_{10}$ (for UV radiation) values, dose and fluence, respectively, lethal for $90 \%$ of the initial population, according to Moeller et al. (2007a, 2007b). Each experiment was repeated at least three times, and the data shown are expressed as averages \pm standard deviations. The treated cells and spores were compared statistically by using the Student $t$ test. Values were analyzed in multigroup pairwise combinations, and differences with $P$ values of $\leq 0.05$ were considered statistically significant (Moeller et al., 2005, 2008).

\section{Results}

To study the adaptiveness of Bacillus subtilis under laboratory conditions, the present experimental setup was designed to direct the evolution of populations of B. subtilis 168 to a higher UV resistance than exhibited by the ancestral population. Our laboratory evolution experiment was carried out for 69 cycles, and we evolved five lines for approximately 700 generations, with four lines periodically irradiated with polychromatic UV and a non-irradiated line as a control. The UV resistance level of each population throughout the experimental evolution was monitored by determining the survival fraction after each irradiation step as described above.

\subsection{Experimental approach simulating microbial evolution}

After 69 completed passage cycles, an overall increase in the UV resistance was detectable in all four evolution lines, whereas cells of the non-irradiated control line (C69) showed no alteration in UV resistance and were inactivated similar to the ancestral cells. As determined by recording inactivation curves, the ancestral bacterial population, founded from one clone, did not contain such resistant bacteria. So, the increased radiation resistance ability appears to be a property acquired during the experiment rather than by way of preferential selection in the ancestral population, though selection cannot be completely ruled out. Thus, we can say the experiments were successful in producing strains that show increased resistance to UV exposure and are, accordingly, well adapted to the experimentally changed environmental conditions. 


\subsection{Systematic evaluation on the UV radiation resistance}

To investigate the adaptation to polychromatic UV radiation in the range from 200 to $400 \mathrm{~nm}$, which is the primary selective agent, $F_{10}$ values were calculated from the inactivation curves shown in Fig. 2A, which were recorded in PBS: $769.3 \pm 35.6 \mathrm{~J} / \mathrm{m}^{2}$ for the ancestral strain (A) and $3351.5 \pm 146.6 \mathrm{~J} / \mathrm{m}^{2}$ for MW01 (4.5-fold increase). Cells of the control strain DE69 exhibited under all tested conditions no significant alterations in relation to A (Fig. 2A).

Because of the sharp damage profile (see below) and the intent to compare the results with literature data, $254 \mathrm{~nm} \mathrm{UV}$ radiation was selected for recording inactivation curves for further characterization of the altered UV resistance level of evolved populations. The determined $F_{10}$ values, $27.9 \pm$ $1.9 \mathrm{~J} / \mathrm{m}^{2}$, $1 \mathrm{E} 6981.6 \pm 2.6 \mathrm{~J} / \mathrm{m}^{2}$ (2.9-fold increase), $2 \mathrm{E} 69$ $68.4 \pm 3.0 \mathrm{~J} / \mathrm{m}^{2}$ (2.5-fold increase), 3E69 $68.4 \pm 3.9 \mathrm{~J} / \mathrm{m}^{2}(2.5-$ fold increase), and $4 \mathrm{E} 6959.3 \pm 3.7 \mathrm{~J} / \mathrm{m}^{2}$ (2.1-fold increase), representing the UVC fluence needed to be applied to inactivate a population by $1 \mathrm{log}$, showed that the level of adaptation reached in the course of the experimental evolution was not identical within the four UV-exposed populations. Later in this paper, we will focus on the changes in line $1 \mathrm{E}$ based on the highest ranking of adaptation to UVC radiation (Table 2).

To investigate the development of the increased UV resistance in the course of the experiment, we recorded UVC inactivation curves (Fig. 2B) of every $10^{\text {th }}$ mixed population archived from line $1 \mathrm{E}$ during the experimental evolution. $F_{10}$ values were calculated from these inactivation curves (Table 2). As can be determined from Fig. 3, the $F_{10}$ values evince an adaptation that took place in two major steps. The first significant increase in UVC resistance was observed after 30 completed passage cycles (2.2-fold increase relative to A), the second one after 40 completed passage cycles (3.1fold). Subsequent populations exhibited no further statistically significant alterations in UVC resistance (Fig. 3). At this point, single-colony isolates were taken from populations 1E69 and C69 to generate purified strains that were tested for their radioresistance. Strains exhibiting the mean UV resistance level of the corresponding mixed population were chosen for further characterizations and were designated MW01 (derived from 1E69) and DE69 (from C69). For the ancestral strain, the $F_{10}$ value recorded in PBS was about $27.9 \pm 1.9 \mathrm{~J} / \mathrm{m}^{2} \mathrm{UVC}$. In contrast, a high $F_{10}$ value observed for strain MW01 was $81.6 \pm 2.6 \mathrm{~J} / \mathrm{m}^{2}$ (Fig. 3). These results suggest that the tolerance of MW01 is about 3-fold higher than that of the ancestor. $F_{10}$ values recorded in growth medium where a substantial amount of UVC radiation is absorbed by the components of the medium show alterations in the same range, $750.7 \pm 40.2 \mathrm{~J} / \mathrm{m}^{2}$ (A) and $2201.5 \pm 156.6 \mathrm{~J} / \mathrm{m}^{2}$ (MW01) (Wassmann et al., unpublished data).

\subsection{Desiccation}

Cells of populations A, DE69, and MW01 were air-dried on glass slides under laboratory conditions, and survivability was tested after different periods of desiccation. Within the first $24 \mathrm{~h}$ of desiccation, cells of populations A and DE69 were inactivated by 5 orders of magnitude; at later time points, no survivors for A were detectable. Cells of population DE69 were inactivated by another 2 orders of magnitude within the next $24 \mathrm{~h}$, and in later stages the survival rate did not change significantly. In contrast, 1\% of MW01 cells

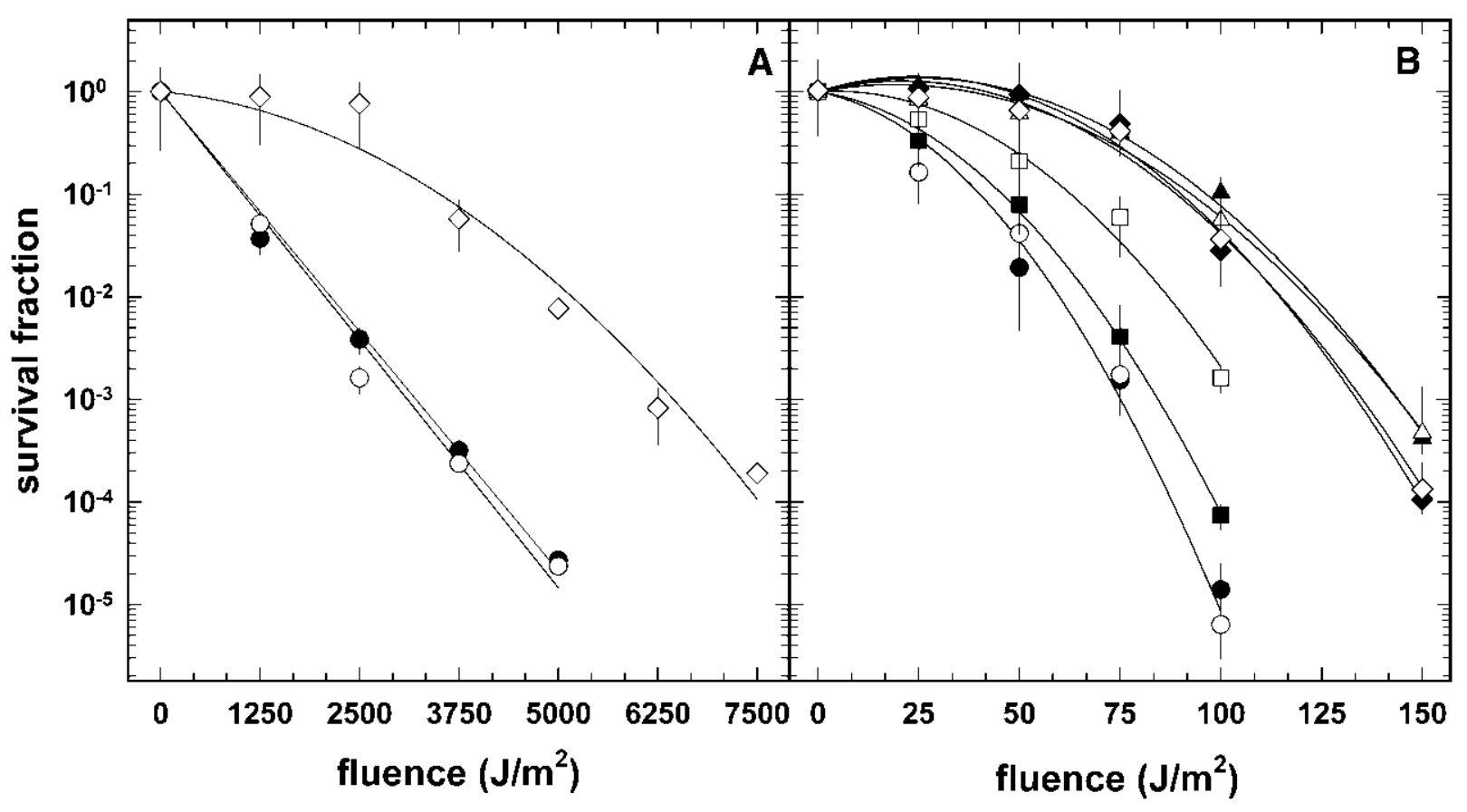

FIG. 2. Survival curves of B. subtilis cells in response to $200-400 \mathrm{~nm}$ (A) and $254 \mathrm{~nm}$ (B) UV radiation. Populations (i.e., number of elapsed UV exposure cycles) were ancestral A (filled circles), $\mathrm{E}_{10}$ (open circles), $\mathrm{E}_{20}$ (filled squares), $\mathrm{E}_{30}$ (open squares), $\mathrm{E}_{40}$ (open triangles), $\mathrm{E}_{50}$ (filled triangles), $\mathrm{E}_{60}$ (filled diamonds), and $\mathrm{E}_{69}$ (open diamonds). Data are expressed as averages \pm standard deviations $(n=3)$. Error bars for survival data not visible were smaller than the symbol. 
Table 2. Resistance of Growing Ancestral Cells, with UV Irradiance-Evolved Cells, and without UV Irradiance-Evolved Cells of Bacillus subtilis to Various Environmental Stressors

\begin{tabular}{|c|c|c|c|}
\hline \multirow[b]{2}{*}{$\begin{array}{l}\text { Decimal reduction values } \\
\left(\mathrm{D}_{10}\right) \text { values }{ }^{\mathrm{a}} \text { for cells exposed to }\end{array}$} & \multicolumn{3}{|c|}{ UV exposure cycle (generations) } \\
\hline & Ancestral cells A (0) & $\begin{array}{c}\text { UV-evolved cells } \\
\text { MW01 (700) }\end{array}$ & $\begin{array}{c}\text { Dark-evolved } \\
\text { cells DE69 (700) }\end{array}$ \\
\hline X-rays $(\mathrm{Gy})^{\mathrm{b}}$ & $95.2 \pm 13.4^{\mathrm{c}}$ & $751.1 \pm 62.5^{\mathrm{c}, \mathrm{d}, *}$ & $121.3 \pm 24.1^{\mathrm{c}}$ \\
\hline $1 M \mathrm{NaCl}(\min )^{\mathrm{e}}$ & $8.1 \pm 2.0$ & $58.1 \pm 5.9^{*}$ & $12.3 \pm 3.1$ \\
\hline $10 \mathrm{mM} \mathrm{H}_{2} \mathrm{O}_{2}(\mathrm{~min})^{\mathrm{f}}$ & $3.2 \pm 0.6$ & $12.4 \pm 1.8^{*}$ & $4.8 \pm 1.1$ \\
\hline $55^{\circ} \mathrm{C}$ wet heat $(\min )^{\mathrm{g}}$ & $4.1 \pm 0.6$ & $4.5 \pm 0.3$ & $4.3 \pm 0.4$ \\
\hline
\end{tabular}

${ }^{\mathrm{a}} D_{10}$ (i.e., dose or time), reducing the survival of the B. subtilis cell population to $10 \%$.

${ }^{\mathrm{b}}$ Ionizing radiation was provided in the form of X-rays $(150 \mathrm{keV} / 19 \mathrm{~mA})$.

${ }^{\mathrm{c}}$ Data were derived from Fig. 4.

${ }^{\mathrm{d}}$ Value obtained by extrapolation.

${ }^{\mathrm{e} C e l l s}$ were exposed to a high salinity $(1 \mathrm{M} \mathrm{NaCl})$.

${ }^{\mathrm{f}}$ Cells were exposed to hydrogen peroxide $\left(10 \mathrm{mM} \mathrm{H} \mathrm{H}_{2} \mathrm{O}_{2}\right)$.

${ }^{g}$ Cells were treated with wet heat $\left(55^{\circ} \mathrm{C}\right)$.

Data are averages and standard deviations $(n=3)$. Asterisks $\left(^{*}\right)$ indicate survival values that were significantly different than ancestral cells of B. subtilis $(P \leq 0.05)$.

survived the first 2 days of desiccation. After 5 days, $10^{3}$ of originally $10^{8}$ cells had survived, and within the next 2 days viable cells were subsequently reduced by 1 order of magnitude. As is summarized in Fig. 4, short-term desiccation tolerance increased significantly in the UV-evolved popula-
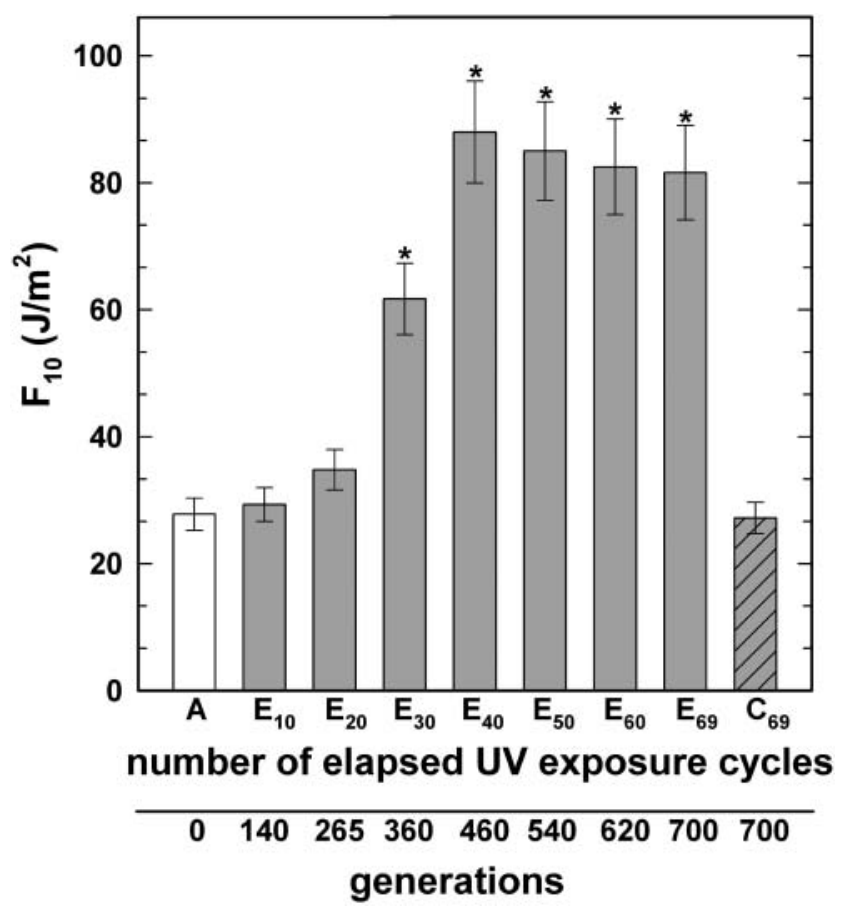

FIG. 3. B. subtilis cell resistance to $254 \mathrm{~nm}$ UVC. $F_{10}$ values are expressed as averages \pm standard deviations $(n=3)$. The asterisks indicate $F_{10}$ values that were significantly different than the $F_{10}$ value for the ancestral cells, as determined by the Student $t$ test $(P \leq 0.05)$. Number of elapsed UV exposure cycles were ancestral A (white bar), UV-evolved $E_{10-69}$ (gray bars), and dark-evolved control $\mathrm{C}_{69}$ (gray shaded bar). Second $x$ axis shows the number of generations of the respective UV-evolved cultivation cycle. The number of generations was determined as described in the text (cf. Materials and Methods). tion in the course of the experimental evolution (Fig. 4). Survivors of all populations were also enumerated after heat shocking, which ensured that the observed increased desiccation tolerance of strain MW01 was not based on a higher fraction of spores in the original solution. Quite the contrary

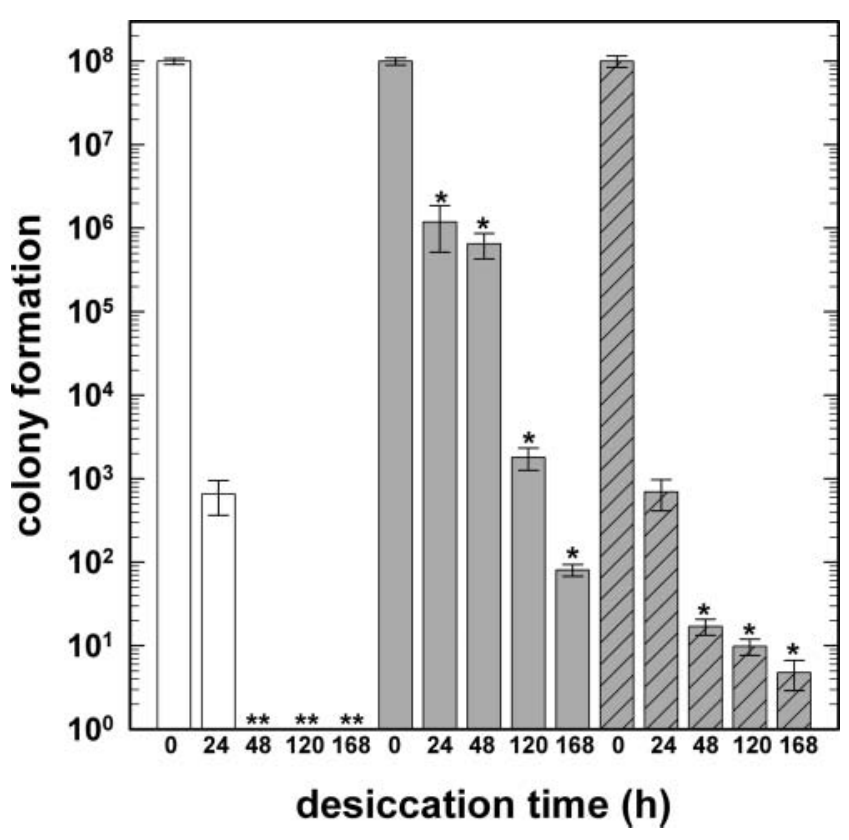

FIG. 4. B. subtilis cell resistance to desiccation (at $20^{\circ} \mathrm{C}$, $33.1 \pm 3.5$ relative humidity). Strains (i.e., number of elapsed UV exposure cycles) were ancestral A (white bars), UVevolved MW01 (gray bars), and dark-evolved control DE69 (gray shaded bars). One asterisk indicates colony formation rates that were significantly different than the respective colony formation rates for ancestral cells, as determined by the Student $t$ test $(P \leq 0.05)$. Colony formation ability is expressed as averages \pm standard deviations $(n=3)$. Two asterisks indicate colony formation rates that dropped below the threshold of detection of $10^{-8}$. The "detection threshold" for colony formation is defined by the initial cell count. 
was observed: the amount of spores in MW01 cell solution was below the threshold level of detection.

\subsection{Changes in level of $X$-ray resistance}

Additional experiments showed alterations in resistance to ionizing radiation provided in the form of $X$-rays. $D_{10}$ values, doses of $X$-rays required to reduce a population by $1 \log$, were calculated from recorded X-ray inactivation curves. For vegetative ancestral cells tested for their resistance, the $D_{10}$ was about $92.0 \pm 8.5 \mathrm{~Gy}$, whereas for MW01 cells $624.9 \pm 13.4$ Gy was calculated, which shows that MW01 cells were 6.8-fold more resistant than the ancestral cells (Fig. 5).

\subsection{Further stressors and physiological changes}

Cells of strains A, DE69, and MW01 were additionally tested in their resistance to increased osmolarity, oxidative stress, and moderate wet heat (Table 2). Cells were exposed to the named conditions, and the level of tolerance was determined by measuring the time until decimal reduction $\left[D_{10}\right.$ (min)]. In response to increased salt stress $(1 \mathrm{M} \mathrm{NaCl})$, cells of strains A $\left(D_{10}=8.1 \pm 2.0 \mathrm{~min}\right)$ and $\mathrm{DE} 69\left(D_{10}=12.3 \pm 3.1\right.$ min) exhibited more or less similar reduction by 1 order of magnitude, whereas the time for decimal reduction of MW01 cells was significantly longer $\left(D_{10}=58.1 \pm 5.9 \mathrm{~min}\right)$, presenting a 7.2-fold increase of tolerance to these conditions related to the ancestor. Similar alterations were observed in the tolerance to oxidative stress $\left(10 \mathrm{mM} \mathrm{H}_{2} \mathrm{O}_{2}\right)$. Cells of strains A and DE69 were inactivated comparably, whereas MW01 exhibited a 3.8-fold increase in time to decimal reduction $\left(D_{10}=\mathrm{A} 3.2 \pm 0.6 \mathrm{~min}\right.$ and $D_{10}=$ MW01 $\left.12.4 \pm 1.8 \mathrm{~min}\right)$. In their tolerance to $55^{\circ} \mathrm{C}$ wet heat, no significant alteration between cells of all tested strains was observed; the average decimal reduction time was $4.3 \mathrm{~min}$ (Table 2). Early in the course of the experiment, starting within the first 10 passage cycles, changes in cell and colony morphology took place. Two different assays were performed on a regular basis to verify the taxonomic identity of the evolved strains and population; that is, a physiological marker test of the colonies from the experiment samples (Horneck et al., 2001, 2008; Zeigler et al., 2008) and partial sequence analyses of the $B$. subtilis $16 \mathrm{~S}$ rDNA were carried out to check for contamination of the samples. On solid NB growth medium, the ancestral strain grew as brown colonies after 3 days of incubation at $37^{\circ} \mathrm{C}$ and showed the beginning of sporulation induced by nutrient limitation. In contrast, colonies that arose from evolved populations partially exhibited decreased pigmentation and, with increasing number of elapsed cycles, yielded more and more transparent colonies, a phenotype which is characteristic of sporulation-defective $\left(\mathrm{Spo}^{-}\right) B$. subtilis mutants (Piggot and Coote, 1976). This was in good accordance with the significant decrease in sporulation efficiency of all UV-irradiated lines (mixed populations 1-4E69) in liquid sporulation medium (data here not shown; publication in preparation). Additionally, cell size in stationaryphase populations increased. As estimated from microscopic observations, cells of the MW01 strain appeared about 2 times longer than ancestral cells.

\section{Discussion}

As reviewed by Cockell and Horneck (2001), numerous lines of isotopic and geological evidence suggest that the

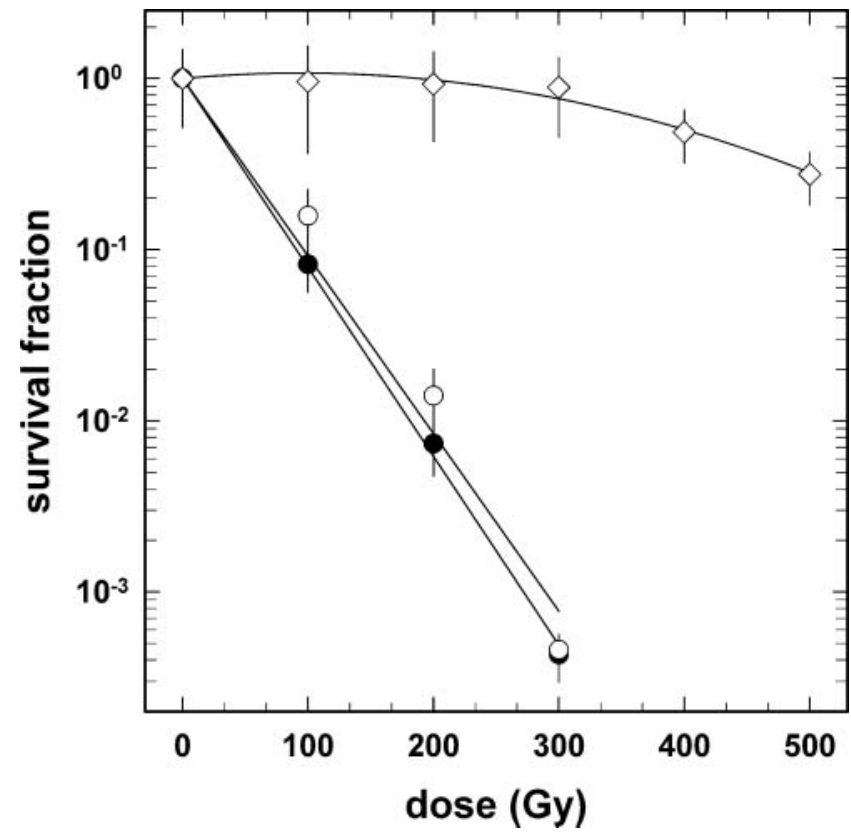

FIG. 5. Survival curves of B. subtilis cells in response to sparsely ionizing radiation (X-rays), significantly different than the $F_{10}$ value for ancestral cells, as determined by the Student $t$ test $(P \leq 0.05)$. Numbers of elapsed UV exposure cycles were ancestral A (filled circles), UV-evolved MW01 (open diamonds), and dark-evolved control DE69 (open circles). Data are expressed as averages \pm standard deviations $(n=3)$.

Archean atmosphere was essentially anoxic (Walker et al., 1983; Lowe, 1994; Holland, 1999, 2006) and did not absorb the energy-rich short UV wavelengths as is the case today with the absorption of ozone. Thus, UVB (280-315 nm) radiation as well as UVC $(200-280 \mathrm{~nm})$ radiation has penetrated to Earth's surface, with their associated biological consequences (Margulis et al., 1976; Cockell, 1998).

Previous experiments have shown that it is possible to induce alterations in the radiation resistance of different microorganisms. Luckiesh and Knowles (1948) demonstrated in a study of Escherichia coli a doubling of UV radiation resistance after five successive sublethal UV radiation treatments of surviving populations compared to the ancestral population. Parisi and Antoine $(1974,1977)$ obtained a 4-fold increase in vegetative cell radiation resistance of Bacillus pumilus by repeated passage of resistant survivors through successive sublethal doses of ${ }^{60}$ Co irradiation. Ewing (1995, 1997) produced a series of radiation-resistant strains of Escherichia coli by daily irradiation with X-rays. And, most recently, Harris et al. (2009) again generated extreme ionizing radiation resistance in $E$. coli by directed evolution under reoccurring ${ }^{60} \mathrm{Co}$ irradiation and characterized the evolved populations by using new technologies.

In this study, experiments were performed to determine the adaptability of $B$. subtilis to periodic exposure of high fluences $\left(16.8 \mathrm{~kJ} / \mathrm{m}^{2}\right)$ of polychromatic UV radiation. In the early Proterozoic, approximately $2.1 \mathrm{Ga}$ ago, Earth's atmosphere was subject to rapid oxidation. The UV radiation in Earth's orbit is unattenuated by Earth's atmosphere, and it represents a natural source of solar radiation (Cockell, 1998; 
Cockell and Horneck, 2001). Taking the data of UV fluxes on early Earth from Cockell (1998) into account, it can be stated that the UV-evolved strain MW01 would survive $2 \mathrm{~min} 30 \mathrm{~s}$ $\left(F_{10-6}=10.9 \mathrm{~kJ} / \mathrm{m}^{2}\right)$ unattenuated under these UV climate conditions until reaching an inactivation by 6 orders of magnitude, which is approximately 1.7 times longer than the ancestral (A) and the parallel-evolved (UV-shaded) strain (DE69) $\left[F_{10-6}=6.5 \mathrm{~kJ} / \mathrm{m}^{2}\right.$ (A) $1 \mathrm{~min} 30 \mathrm{~s}, F_{10-6}=6.7 \mathrm{~kJ} / \mathrm{m}^{2}$ (DE69) 1 min 32s].

The spectrum applied throughout the experimental evolution, 200-400 nm wavelength including UVA, UVB, and UVC, is known to induce a variety of lesions harmful to cellular integrity (reviewed in Sinha and Häder, 2002; Cadet et al., 2005 , and references therein). UVB radiation acts mostly on DNA through the direct excitation process of the nucleobases, and further reactions proceed in an oxygen-independent manner. This leads predominantly to the formation of dimeric photoproducts at bipyrimidine sites that involve cis-syn cyclobutadipyrimidines and pyrimidine (6-4) pyrimidone photoproducts. On the other hand, most of the damaging effects of UVA radiation on cellular DNA involve photosensitization reactions, since nucleobases have a weak absorption rate above $320 \mathrm{~nm}$ (Cadet et al., 2005). The exposure to UVC radiation ( $254 \mathrm{~nm}$ wavelength), the most mutagenic part of the periodically applied spectrum, leads to alteration of the DNA bases, which results mostly in formation of dimeric photoproducts (Cadet et al., 2005). As mentioned above, UVC radiation was selected for further characterizations of the altered UV resistance level of evolved populations.

Our evolution experiment tested the prediction that organisms that have enzymatic repair pathways generated during evolution are well suited for repairing DNA damage that occurs after natural radiation levels but are not well suited for repairing the large amount of DNA lesions induced during a laboratory experiment in which it is common to use fluences that are orders of magnitude larger than cells encountered as they evolved. So the possibility for further evolution should exist. Ewing $(1995,1997)$ produced, via daily irradiation with X-rays, a series of strains of Escherichia coli that were resistant to both $\mathrm{X}$-rays and UV radiation. P1 transduction experiments showed that all the acquired resistance was lost when SOS response-mediated repair was genetically blocked, which led to the conclusion that the acquired resistance was based on changes in association with SOS repair. The term cellular SOS response (Witkin, 1976; Love and Yasbin, 1984; Au et al., 2005) covers the commonly regulated expression of genes coding for a variety of DNA repair mechanisms identified in both prokaryotic and eukaryotic cells in response to DNA damage produced by UVC radiation and other genotoxic agents. Repair mechanisms include direct damage reversal, base excision repair, nucleotide excision repair (Cadet et al., 2005), mismatch correction, and recombination repair [for a review on UV-mediated damage repair in bacteria, see Goosen and Moolenaar (2008 and references therein)].

In the course of our experimental evolution, we were successful in isolating stable populations that showed increased resistance to UV exposure in relation to the ancestral population. The UVC inactivation curves obtained for every $10^{\text {th }}$ population, which were isolated and archived from line $1 \mathrm{E}$ during the experimental evolution, illustrate a graduated two-stage change in resistance (Fig. 2) and may indicate that more than one mutational event has occurred, each contributing independently or synergistically to an increased resistance. In hindsight, we know that the final resistance level in the total number of generations observed here was reached after about 40 passage cycles. However, experimental evolution was carried on for another 29 cycles without any further visible alterations in physiological behavior of the cells. The applied polychromatic UV, which acted as the evolutionary driving force in this experiment and put great selection pressure on periodically exposed populations, reduced the ancestral population by 3 logs. Populations adapted to these conditions were significantly less reduced by the applied fluence (50-70\% 1E40 - 1E69). For the evolved populations, the selection pressure of the applied UV treatment was clearly decreased.

The acquired UV resistance prompted an initial study on the underlying mechanisms. UVC-induced bipyrimidine photoproducts are removed by nucleotide excision repair. Starting from the assumption that mutations in the sequences of the genes (uvrA, uvrB, and uvrC) coding for the main three enzymes of this DNA repair pathway in $B$. subtilis could have led to the increased UV tolerance, the three $u v r$ genes of the ancestral strain (A) and the higher UV-resistant strain (MW01) were sequenced and compared. Interestingly, no differences in the coding sequences of the genes of the $\mathrm{A}$ and the MW01 strains were found (data not shown).

In addition to the increased UV resistance, we also observed higher survival of the cells that evolved under UV stress compared to survival of the ancestral strains, while it is known that the two different qualities of radiation induce mainly different types of lesions to cellular DNA. There are two alternative routes of ionizing radiation damage to biological components such as proteins, RNA, and DNA: direct energy absorption (direct radiation effect) and interactions with radicals, for example, those produced by radiolysis of cellular water molecules (indirect radiation effect) (Hutchinson, 1985). Both processes mainly cause single strand breaks or double strand breaks in DNA (Hutchinson, 1985; Dose et al., 1991, 1992; Dose and Gill, 1995; Nicastro et al., 2002). As the irradiation of a complex medium with UVA radiation (which was part of the periodically applied spectrum) results in the formation of reactive oxygen species, the reported increase in tolerance to oxidative stress is not surprising. It represents an adaptation, indirectly caused by irradiation, to an additional stressor acting on evolving populations in the experimental environment. Our results, in good accordance with Ewing's conclusion, indicate that the molecular alterations underlying the adaptation that occurred in evolved cells are not specified on a single lesionspecific repair pathway but rather are involved in general stress response, for example, in the regulation of the cellular SOS response (Goosen and Moolenaar, 2008, and references therein). Further analyses, such as radiation-induced lesion analysis, repair kinetics, and transcriptional profiling, are in preparation and will hopefully lead to further insights.

The observed loss of sporulation efficiency in the course of the experimental evolution, which was indicated by the increased number of $\mathrm{Spo}^{-}$colonies, was similar to observations reported in space exposure experiments (FajardoCavazos et al., 2005). Interestingly, the major mutagenic factor that led to the Spo ${ }^{-}$phenotype mentioned by FajardoCavazos et al. was solar UV in low Earth orbit that was 
unfiltered by the atmosphere, which indicates a spectral range of $200-400 \mathrm{~nm}$. In contrast to their progenitor vegetative cells, spores of strain MW01 exhibited no altered radiation tolerance and were inactivated almost to the same extent by UVC and X-ray irradiation as were the spores from the ancestor (data not shown). This may be based on the different DNA repair pathways and protection mechanisms of dormant spores compared to those of vegetative cells. Spores possess thick layers of highly cross-linked coat proteins, a modified peptidoglycan spore cortex, a low core water content, and abundant intracellular constituents such as the calcium chelate of dipicolinic acid (Ca-DPA) and a special group of small, acid-soluble spore proteins that protect spore DNA (reviewed in Nicholson et al., 2000; Nicholson, 2009, and references therein). These morphological attributes are only present in the spore state and therefore cannot protect the DNA in vegetative cells. DNA damage that accumulates during spore dormancy is repaired during germination by spore-specific DNA repair pathways. For example, the major UV-induced DNA photoproduct, the spore photoproduct, is repaired by spore photoproduct lyase (reviewed in Nicholson et al., 2000); DNA double-strand breaks are repaired by non-homologous end-joining (Moeller et al., 2007b, 2008); and oxidative stress-induced apurinic/ apyrimidinic sites are repaired by apurinic/apyrimidinic endonucleases (Ibarra et al., 2008). Vegetative cells, however, respond directly to induced DNA lesions by a varied set of DNA repair mechanisms other than those of DNA-damaged spores, which are primarily active during germination (Nicholson et al., 2000; Au et al., 2005; Moeller et al., 2007a, 2007b, 2008; Nicholson, 2009). Since the spore resistance to UVC of the UV-evolved strain MW01 and the ancestor show no significant differences, we assume that only changes (mutations) have occurred in the DNA repair mechanisms used by vegetative cells and not (or less) by those activated by spores during germination (further work on the changes in nucleotide composition of all known DNA repair pathways in these two investigated strains is in progress).

Nevertheless, further experiments are ongoing and investigating the resistance of spores to different environmental stressors; for example, in the frame of the space experiment ADAPT, which is mounted externally on the Columbus module of the International Space Station, several highly resistant microorganisms from different terrestrial habitats (including spores of $B$. subtilis strains A and MW01) have been exposed for 18 months to space and simulated martian conditions (including radiation, vacuum, and desiccation).

In conclusion, the results from the experiments reported here show clearly that, under the selective pressure of frequently applied UV stress, a significant increased level in the cell resistance of $B$. subtilis to UV and other environmental stressors (e.g., desiccation, high salinity, and hydrogen peroxide) could be reached. This demonstrates that active processes under the influence of a major stress, in our study of high fluences of UV radiation, ensure microbial survival, growth, and reproduction even under the loss of key physiological processes (e.g., sporulation).

\section{Acknowledgments}

The authors are grateful to Heather Maughan for her comments on the manuscript. We express our gratitude to
Mary Köhler for her critical reading of the manuscript. We thank the two anonymous reviewers for their valuable comments. These results will be included in the $\mathrm{PhD}$ thesis of Marko Wassmann.

\section{Author Disclosure Statement}

No competing financial interests exist.

\section{Abbreviations}

ADAPT, Molecular adaptation strategies of microorganisms to different space and planetary UV climate conditions [more details can be obtained in the documents of the European Space Agency (ESA), Announcement of Opportunity (AO) proposal/project No. ESA-AO2004-149]; NB, nutrient broth; PBS, phosphate-buffered saline; PCR, polymerase chain reaction; $\mathrm{Spo}^{-}$, sporulation defective.

\section{References}

Anagnostopoulos, C. and Spizizen, J. (1961) Requirements for transformation in Bacillus subtilis. J. Bacteriol. 81:741-746.

$\mathrm{Au}$, N., Kuester-Schoeck, E., Mandava, V., Bothwell, L.E., Canny, S.P., Chachu, K., Colavito, S.A., Fuller, S.N., Groban, E.S., Hensley, L.A., O’Brien, T.C., Shah, A., Tierney, J.T., Tomm, L.L., O'Gara, T.M., Goranov, A.I., Grossman, A.D., and Lovett, S.M. (2005) Genetic composition of the Bacillus subtilis SOS system. J. Bacteriol. 187:7655-7666.

Beblo, K., Rabbow, E., Rachel, R., Huber, H., and Rettberg, P. (2009) Tolerance of thermophilic and hyperthermophilic microorganisms to desiccation. Extremophiles 13:521-531.

Cadet, J., Sage, E., and Douki, T. (2005) Ultraviolet radiationmediated damage to cellular DNA. Mutat. Res. 571:3-17.

Cockell, C.S. (1998) The biological effects of high ultraviolet radiation on early Earth: a theoretical evaluation. J. Theor. Biol. 193:717-729.

Cockell, C.S. and Horneck, G. (2001) The history of the UV radiation climate of the Earth-theoretical and space-based observations. Photochem. Photobiol. 73:447-451.

Dose, K. and Gill, M. (1995) DNA stability and survival of Bacillus subtilis spores in extreme dryness. Orig. Life Evol. Biosph. 25:277-293.

Dose, K., Bieger-Dose, A., Kerz, O., and Gill, M. (1991) DNAstrand breaks limit survival in extreme dryness. Orig. Life Evol. Biosph. 21:177-187.

Dose, K., Bieger-Dose, A., Labusch, M., and Gill, M. (1992) Survival in extreme dryness and DNA-single-strand breaks. Adv. Space Res. 12:221-229.

Elena, S.F. and Lenski, R.E. (2003) Evolution experiments with microorganisms: the dynamics and genetic bases of adaptation. Nat. Rev. Genet. 4:457-469.

Entcheva, P., Liebl, W., Johann, A., Hartsch, T., and Streit, W.R. (2001) Direct cloning from enrichment cultures, a reliable strategy for isolation of complete operons and genes from microbial consortia. Appl. Environ. Microbiol. 67:89-99.

Ewing, D. (1995) The directed evolution of radiation resistance in E. coli. Biochem. Biophys. Res. Commun. 216:549-553.

Ewing, D. (1997) Production of radiation-resistant E. coli strains by daily X-irradiation. Int. J. Radiat. Biol. 71:253-258.

Fajardo-Cavazos, P. and Nicholson, W.L. (2006) Bacillus endospores isolated from granite: close molecular relationships to globally distributed Bacillus spp. from endolithic and extreme environments. Appl. Environ. Microbiol. 72:2856-2863.

Fajardo-Cavazos, P., Link, L., Melosh, H.J., and Nicholson, W.L. (2005) Bacillus subtilis spores on artificial meteorites survive 
hypervelocity atmospheric entry: implications for lithopanspermia. Astrobiology 5:726-736.

Goosen, N. and Moolenaar, G.F. (2008) Repair of UV damage in bacteria. DNA Repair 7:353-379.

Grossman, A.D. (1995) Genetic networks controlling the initiation of sporulation and the development of genetic competence in Bacillus subtilis. Annu. Rev. Genet. 29:477-508.

Hanlin, J.H., Lombardi, S.J., and Slepecky, R.A. (1985) Heat and UV light resistance of vegetative cells and spores of Bacillus subtilis Rec ${ }^{-}$mutants. J. Bacteriol. 163:774-777.

Harris, D.R., Pollock, S.V., Wood, E.A., Goiffon, R.J., Klingele, A.J., Cabot, E.L., Schackwitz, W., Martin, J., Eggington, J., Durfee, T.J., Middle, C.M., Norton, J.E., Popelars, M.C., Li, H., Klugman, S.A., Hamilton, L.L., Bane, L.B., Pennacchio, L.A., Albert, T.J., Perna, N.T., Cox, M.M., and Battista, J.R. (2009) Directed evolution of ionizing radiation resistance in Escherichia coli. J. Bacteriol. 191:5240-5252.

Helmann, J.D., Wu, M.F., Gaballa, A., Kobel, P.A., Morshedi, M.M., Fawcett, P., and Paddon, C. (2003) The global transcriptional response of Bacillus subtilis to peroxide stress is coordinated by three transcription factors. J. Bacteriol. 185:243-253.

Holland, H.D. (1999) When did the Earth's atmosphere become oxic? A reply. The Geochemical News 100:20-22.

Holland, H.D. (2006) The oxygenation of the atmosphere and oceans. Philos. Trans. R. Soc. Lond., B, Biol. Sci. 361:903-915.

Horneck, G., Stöffler, D., Eschweiler, U., and Hornemann, U. (2001) Bacterial spores survive simulated meteorite impact. Icarus 149:285-293.

Horneck, G., Stöffler, D., Ott, S., Hornemann, U., Cockell, C.S., Moeller, R., Meyer, C., de Vera, J.P.P., Fritz, J., Schade, S., and Artemieva, N.A. (2008) Microbial rock inhabitants survive hypervelocity impacts on Mars-like host planets: first phase of lithopanspermia experimentally tested. Astrobiology 8:17-44.

Hutchinson, F. (1985) Chemical changes induced in DNA by ionizing radiation. Prog. Nucleic Acid Res. Mol. Biol. 32:115-154.

Ibarra, J.R., Orozco, A.D., Rojas, J.A., López, K., Setlow, P., Yasbin, R.E., and Pedraza-Reyes, M. (2008) Role of the Nfo and ExoA apurinic/apyrimidinic endonucleases in repair of DNA damage during outgrowth of Bacillus subtilis spores. J. Bacteriol. 190:2031-2038.

Kane, M.D., Poulsen, L.K., and Stahl, D.A. (1993) Monitoring the enrichment and isolation of sulfate-reducing bacteria by using oligonucleotide hybridization probes designed from environmentally derived 16S rRNA sequences. Appl. Environ. Microbiol. 59:682-686.

Lane, D.J. (1991) 16S/23S rRNA sequencing. In Nucleic Acid Techniques in Bacterial Systematics, edited by E. Stackebrandt and M. Goodfellow, John Wiley \& Sons, New York, pp 115175.

Lenski, R.E., Rose, M.R., Simpson, S.C., and Tadler, S.C. (1991) Long-term experimental evolution in Escherichia coli. I. Adaptation and divergence during 2000 generations. Am. Nat. 138:1315-1341.

Love, P.E. and Yasbin, R.E. (1984) Genetic characterization of the inducible SOS-like system of Bacillus subtilis. J. Bacteriol. 160:910-920.

Lowe, D.R. (1994) Early environments: constraints and opportunities for early evolution. In Early Life on Earth, edited by S. Bengston, Columbia University Press, New York, pp 24-35.

Luckiesh, M. and Knowles, T. (1948) Resistivity of Escherichia coli to ultraviolet energy (lambda 2537) as affected by irradiation of preceding cultures. J. Bacteriol. 55:369-372.

Maughan, H., Callicotte, V., Hancock, A., Birky, C.W., Jr., Nicholson, W.L., and Masel, J. (2006) The population genetics of phenotypic deterioration in experimental populations of $\mathrm{Ba}$ cillus subtilis. Evolution 60:686-695.

Maughan, H., Masel, J., Birky, C.W., Jr., and Nicholson, W.L. (2007) The roles of mutation accumulation and selection in loss of sporulation in experimental populations of Bacillus subtilis. Genetics 177:937-948.

Margulis, L., Walker, J.C.G., and Rambler, M. (1976) Re-assessment of the roles of oxygen and ultraviolet light in Precambrian evolution. Nature 264:620-624.

Moeller, R., Horneck, G., Facius, R., and Stackebrandt, E. (2005) Role of pigmentation in protecting Bacillus sp. endospores against environmental UV radiation. FEMS Microbiol. Ecol. 51:231-236

Moeller, R., Douki, T., Cadet, J., Stackebrandt, E., Nicholson, W.L., Rettberg, P., Reitz, G., and Horneck, G. (2007a) UV radiation induced formation of DNA bipyrimidine photoproducts in Bacillus subtilis endospores and their repair during germination. Int. Microbiol. 10:39-46.

Moeller, R., Stackebrandt, E., Reitz, G., Berger, T., Rettberg, P., Doherty, A.J., Horneck, G., and Nicholson, W.L. (2007b) Role of DNA repair by non-homologous end joining (NHEJ) in Bacillus subtilis spore resistance to extreme dryness, mono- and polychromatic UV and ionizing radiation. J. Bacteriol. 189:3306-3311.

Moeller, R., Setlow, P., Horneck, G., Berger, T., Reitz, G., Rettberg, P., Doherty, A.J., Okayasu, R., and Nicholson, W.L. (2008) Roles of the major, small, acid-soluble spore proteins and spore-specific and universal DNA repair mechanisms in resistance of Bacillus subtilis spores to ionizing radiation from $\mathrm{X}$ rays and high-energy charged-particle bombardment. J. Bacteriol. 190:1134-1140.

Nellen, J., Rettberg, P., Horneck, G., and Streit, W.R. (2006) Planetary protection-approaching uncultivable microorganisms. Adv. Space Res. 38:1266-1270.

Nicastro, A.J., Vreeland, R.H., and Rosenzweig, W.D. (2002) Limits imposed by ionizing radiation on the long-term survival of trapped bacterial spores: beta radiation. Int. J. Radiat. Biol. 78:891-901.

Nicholson, W.L. (2009) Ancient micronauts: interplanetary transport of microbes by cosmic impacts. Trends Microbiol. $17: 243-250$.

Nicholson, W.L. and Setlow, P. (1990) Sporulation, germination, and outgrowth. In Molecular Biological Methods for Bacillus, edited by C.R. Harwood and S.M. Cutting, John Wiley \& Sons, New York, pp 391-450.

Nicholson, W.L., Munakata, N., Horneck, G., Melosh, H.J., and Setlow, P. (2000) Resistance of bacterial endospores to extreme terrestrial and extraterrestrial environments. Microbiol. Mol. Biol. Rev. 64:548-572.

Parisi, A.N. and Antoine, A.D. (1974) Increased radiation resistance of vegetative Bacillus pumilus. Appl. Microbiol. 28:41-46.

Parisi, A.N. and Antoine, A.D. (1977) Alterations in radiation resistance of Bacillus pumilus E601 spores. Radiat. Res. 69:367375.

Piggot, P.J. and Coote, J.G. (1976) Genetic aspects of bacterial endospore formation. Bacteriol. Rev. 40:908-962.

Pogoda de la Vega, U., Rettberg, P., Douki, T., Cadet, J., and Horneck, G. (2005) Sensitivity to polychromatic UV-radiation of strains of Deinococcus radiodurans differing in their DNA repair capacity. Int. J. Radiat. Biol. 81:601-611.

Rainey, P.B. and Travisano, M. (1998) Adaptive radiation in a heterogeneous environment. Nature 394:69-72.

Rettberg, P., Fritze, D., Verbarg, S., Nellen, J., Horneck, G., Stackebrand, E., and Kminek, G. (2006) Determination of the 
microbial diversity of spacecraft assembly, testing and launch facilities: first results of the ESA project MiDiv. Adv. Space Res. 38:1260-1265.

Rosenzweig, R.F., Sharp, R.R., Treves, D.S., and Adams, J. (1994) Microbial evolution in a simple unstructured environment: genetic differentiation in Escherichia coli. Genetics 137:903-917.

Sinha, R.P. and Häder, D.P. (2002) UV-induced DNA damage and repair: a review. Photochem. Photobiol. Sci. 1:225-236.

Sniegowski, P.D., Gerrish, P.J., and Lenski, R.E. (1997) Evolution of high mutation rates in experimental populations of E. coli. Nature 387:387:703-705.

Spizizen, J. (1958) Transformation of biochemically deficient strains of Bacillus subtilis by deoxyribonucleate. Proc. Natl. Acad. Sci. U.S.A. 44:1072-1078.

Steil, L., Hoffmann, T., Budde, I., Völker, U., and Bremer, E. (2003) Genome-wide transcriptional profiling analysis of adaptation of Bacillus subtilis to high salinity. J. Bacteriol. 185:6358-6370.

Walker, J.C.G., Klein, C., Schidlowski, M., Schopf, J.W., Stevenson, D.J., and Walter, M.R. (1983) Environmental evolution of the Archean-Proterozoic Earth. In Earth's Earliest Biosphere, edited by J.W. Schopf, Princeton University Press, Princeton, pp 160-190.
Witkin, E.M. (1976) Ultraviolet mutagenesis and inducible DNA repair in Escherichia coli. Bacteriol. Rev. 40:869-907.

Zeigler, D.R., Prágai, Z., Rodriguez, S., Chevreux, B., Muffler, A., Albert, T., Bai, R., Wyss, M., and Perkins, J.B. (2008) The origins of 168, W23, and other Bacillus subtilis legacy strains. J. Bacteriol. 190:6983-6995.

Address correspondence to: Ralf Moeller

German Aerospace Center (DLR) Institute of Aerospace Medicine Radiation Biology Department Research Group "Astrobiology"

Linder Hoehe D-51147 Cologne Germany

E-mail: ralf.moeller@dlr.de

Submitted 26 October 2009 Accepted 29 May 2010 
